\title{
SAMUEL HOWARD AND THE MUSIC FOR THE INSTALLATION OF THE DUKE OF GRAFTON AS CHANCELLOR OF CAMBRIDGE UNIVERSITY, 1769
}

\author{
ALAN HOWARD
}

\begin{abstract}
Samuel Howard (?1710-1782) has long been a familiar inhabitant of the diligent footnotes of Handel biographers. A choirboy in the Chapel Royal, he was a member of Handel's chorus and the composer of much theatre music of his own; he later became organist of both St Bride's, Fleet Street and nearby St Clement Danes, Strand, where he was buried in 1782. His most significant and ambitious work is his fine orchestrally accompanied anthem 'This is the day which the Lord hath made', published posthumously in 1792 with an impressive title page detailing the performance of the work 'at St Margaret's Church before the governors of the Westminster Infirmary, in the Two Universities, and upon many other Publick Occasions in different parts of the Kingdom'. This article confirms for the first time that this work originated as Howard's doctoral exercise, drawing on contemporary press reports and information in the University archives; together these make clear that the composer's doctorate was linked to the provision of music for the Duke of Grafton's installation as Chancellor in 1769. Surviving information about this event offers a glimpse of musical life in Cambridge on a comparable scale to the much better reported proceedings upon similar occasions in Oxford. This evidence then serves as a starting point from which to consider Howard's later prominence as a director of high-profile public performances in London and the provinces.
\end{abstract}

The main protagonist of this paper is one Dr Samuel Howard, long a familiar if shadowy inhabitant of the diligent footnotes of Handel biography. A choirboy in the English Chapel Royal, Howard was discharged in 1733 having been taught by William Croft and, later, Bernard Gates. ${ }^{1}$ He sang tenor in the chorus of Gates's

Earlier versions of this research were presented at the 'Music in Eighteenth-Century Britain' study day at the Foundling Museum, London on 25 November 2016, and at a Faculty Colloquium at Liverpool Hope University on 14 December 2016. I thank Tim Eggington for his interest in the project and for helping to locate several references to performances of Howard's anthem in the 
performance of Handel's Esther in 1732, and performed in Handel's opera chorus for at least one production later in the 1730s (Alcina, in 1735). ${ }^{2}$ Around this time he was a student of Johann Christoph Pepusch, whom he also assisted with the training of the select group of choirboys supported by the Academy of Ancient Music; ${ }^{3}$ in the 1740s he was to serve as librarian of the Academy, an organisation with which he would be associated for the rest of his life. He later became organist of both St Bride's, Fleet Street and nearby St Clement Danes, Strand, where his burial is recorded on 22 July $1782 .^{4}$

I first encountered Howard's name entirely by chance on a piece of publicity material that reproduced an eighteenth-century songsheet ascribed to 'Dr Howard'. Intrigued by this reference, ${ }^{5}$ I soon discovered him to have been the composer of several dozen trifling songs for the theatre, many of which were published in a series of four volumes entitled The Musical Companion, issued between about 1740 and 1758 (this latter date marking the expiry of the Royal Privilege he received from George II in 1744, a year before William Boyce received his own similar privilege ${ }^{6}$ ). This body of works seems to have been popular in his day, though it won him few plaudits from the likes of Charles Burney:

1770s; thanks also to Harry Johnstone, who read and commented upon an earlier version of the present text.

1 Donald Burrows, Handel and the English Chapel Royal (Oxford: OUP, 2005), 252, 393 n.28, 575.

2 Burrows, Handel and the English Chapel Royal, 289, 299 n.35, 301, 393 n.28.

3 Donald F. Cook, 'The Life and Works of Johann Christoph Pepusch (1667-1752), with Special Reference to his Dramatic Works and Cantatas' (unpublished Ph.D. thesis, King's College, London, 1982), volume I, 77 n.12, 321-322; Tim Eggington, The Advancement of Music in Enlightenment England: Benjamin Cooke and the Academy of Ancient Music (Woodbridge: Boydell \& Brewer, 2014), 47, 85; H. Diack Johnstone, 'Westminster Abbey and the Academy of Ancient Music: A Library once Lost and now Partially Recovered', Music \& Letters 95/3 (2014), 329-373 at 332, 370.

4 For general accounts of Howard see Roger Fiske, 'Howard, Samuel', Grove Music Online, $<$ www.oxfordmusiconline.com> (26 September 2016); Louisa M. Middleton, 'Howard, Samuel (1710-1782)', rev. K. D. Reynolds, Oxford Dictionary of National Biography, $<$ http://www.oxforddnb.com> (29 Sept 2016).

5 I am aware of no direct family connection, however.

6 Samuel Howard, The Musical Companion, volume IV (London: John Walsh, [c.1754]). The date given here is from the British Library Catalogue entry for shelfmark G.347.a; the Privilege is printed immediately after the title page. 
The ballads of the late Dr. Samuel Howard, which were long the delight of natural and inexperienced lovers of Music, had the merit of facility; for this honest Englishman, brought up in the Chapel Royal, preferred the style of his own country to that of any other so much, that he never staggered his belief of its being the best in the world, by listening to foreign artists or their productions. ${ }^{7}$

Louisa Middleton glossed this view for her entry in the old Dictionary of National Biography with the damning assessment that 'His style was dull, even in his most admired "musettes". ${ }^{8}$ On the other hand, there is much to admire in his accomplished music for The Amorous Goddess (1744), richly praised by Fiske, including a spirited Handelian French Overture with a tightly-worked fugue, an extensive suite of instrumental pieces including one of the 'musettes' noted by Middleton, and two attractive songs for soprano accompanied by treble instrument, viola and continuo. ${ }^{9}$ One of the latter is a fully fledged da capo aria in the concise style of Howard's teacher Pepusch, a form that Howard also deploys to good effect in his cantata 'Damon, who long deny'd Love's pow'r'. ${ }^{10}$

By far Howard's most significant and ambitious work, however, is his anthem 'This is the day which the Lord hath made', scored for SATB soloists and chorus together with an orchestra of trumpets and timpani, horns, oboes and strings (plus one aria with transverse flute). Although it has not to my knowledge been revived since the eighteenth century, several modern writers have alluded to its quality. ${ }^{11}$ Its six movements speak well of Howard's comfort within a broadly Handelian idiom, together with his strong affinity - as would be expected of a stalwart Academician -

7 Charles Burney, A General History of Music, from the Earliest Ages to the Present Period, volume 4 (London: Author, 1776), 672.

8 Louisa M. Middleton, 'Howard, Samuel (1710-1782)', Dictionary of National Biography Archive (originally published 1892), <http://www.oxforddnb.com> (10 November 2016).

9 Samuel Howard, The Overture, Act Tunes, and Songs, in the Entertainment call'd the Amorous Goddess . . for the Harpsichord, German Flute, or Violin (London: John Walsh, [1744]); see Fiske, 'Howard, Samuel', Grove Music Online.

${ }^{10}$ Samuel Howard, A Cantata and English Songs Set to Music by Mr Howard (London: John Walsh, [c.1750]).

11 '... a splendid anthem ... the opening chorus, largely fugal, is remarkably vigorous' (Fiske, 'Howard, Samuel', Grove Music Online); ‘. . . a fine anthem' (Middleton, rev. Reynolds, 'Howard, Samuel', $O D N B$ Online); ‘. . his impressive orchestral anthem' (Eggington, The Advancement of Music, 85). 
with the music of English composers prior to his own generation. ${ }^{12}$ Thus the first movement in particular owes much in terms of melodic material and orchestral treatment to the first movement of Handel's coronation anthem 'The King shall Rejoice' (a work that Howard would have sung as a Chapel Royal boy at the 1727 coronation of George II). ${ }^{13}$ Tim Eggington draws attention to the lower-voice trio in the last movement of Howard's anthem ('Yea, they shall sing'); with its flowing triple-time and alternation between verse and chorus interjections this movement is indeed redolent of Purcell (think 'Rejoice in the Lord Alway'), as is the pairing of a brief duple-time arioso for bass soloist with a lively triple-time section in Howard's second movement. In formal terms Howard's use of massive choral homophony to introduce an extended fugal working (again in his opening movement) strongly calls to mind the final choruses of both 'With noise of Cannon' and 'Laurus Cruentas', by his erstwhile master William Croft. These two odes were published together as Musicus Apparatus Academicus in about 1720, and Howard may have owned a copy in his extensive library; ${ }^{14}$ composed in celebration of the Peace of Utrecht in 1713 , they were originally presented in Oxford as Croft's doctoral exercise, at the same time as Howard's teacher,

12 A detailed assessment of the work is beyond the scope of this article; since my argument later on hinges upon Howard's ideological commitment to 'Ancient' music, however, it is useful to establish this stylistic association at the outset - however superficially. A modern edition is in press: Samuel Howard, This is the Day which the Lord hath Made: Anthem for soprano, alto and bass soloists, chorus and orchestra, ed. Alan Howard (Mytholmroyd: Green Man / Peacock Press, forthcoming in 2017). This will facilitate more sustained consideration of the work alongside existing studies of related repertoire; see for example Monte Edgel Atkinson, 'The Orchestral Anthem in England, 1700-1775' (D.M.A. dissertation, University of Illinois at Urbana-Champaign, 1991); Donald Burrows, Handel and the English Chapel Royal; H. Diack Johnstone, 'The Life and Work of Maurice Greene (1696-1755)' (D.Phil. thesis, University of Oxford, 1968); John A. Van Nice, 'The Larger Sacred Choral Works of William Boyce (1710-1779)' (Ph.D. thesis, University of Iowa, 1956).

13 I thank Peter Holman for alerting me to the similarities between Handel's and Howard's anthems.

14 Collection of Old Music: A Catalogue of the Greater Part of the Valuable Collection of Vocal and Instrumental Music, Late the Property of Dr. Samuel Howard, Deceased . . which will be Sold by Auction by Mr. White . . on Tuesday, June 25, 1799 (London, British Library, Hirsch IV.1083a); see page 5, item 39. The description ('Two Odes, Oxford, 2 Songs, Dr. Boyce, and an Ode, Dr. Croft') is admittedly ambiguous, but in the absence of obvious candidates for these works among Boyce's music Croft's publication looks likely. A manuscript copy of Handel's 'The King Shall Rejoice' is also listed under item 76, page 7. 
Johann Christoph Pepusch, also received his D.Mus. ${ }^{15}$

The notion that Howard might have looked back to Croft's doctoral odes when composing his anthem is particularly attractive given that, when published in 1792 , the title page of 'This is the day' carried an advertisement to the effect that it had been performed 'in the Two Universities' (see Figure 1), ${ }^{16}$ an observation that has given rise to speculation that this was the work that Howard presented as his own doctoral exercise in $1769 .{ }^{17}$ This hunch in fact turns out to have been quite accurate confirmation of which, incidentally, offers a further measure of the conservative style of Howard's anthem by way of its stark contrast with that of Charles Burney's exactly contemporary D.Mus. exercise (the anthem 'I will love thee, O Lord my Strength'), with its 'reference to the new symphonic style', the 'expressive gestures [of its opening sinfonia] more akin ... to the style of C. P. E. Bach and Haydn than to the archaic pomp of the Baroque overture'. ${ }^{18}$ Moreover, information recoverable from University archives and contemporary press reports usefully illustrates the process by which Cambridge musical doctorates were awarded in the eighteenth century, as well as the nature of the festive framework within which Howard's ode was originally performed. Much of what follows is devoted to this event, which was organized to celebrate the installation of the Duke of Grafton as Chancellor of the University in July 1769; this provides a glimpse of musical life in Cambridge on a comparable scale to the much better reported proceedings upon similar occasions in Oxford. ${ }^{19}$ Furthermore, and since this single event is only part of the story hinted at on the title page of the anthem, a final section considers the subsequent performance history of 'This is the day', which for a time was among the most frequently repeated works at the concerts of subscription series, annual charity events and festivals in the capital and beyond. It soon becomes

\footnotetext{
15 See H. Diack Johnstone, 'Music and Drama at the Oxford Act of 1713', in Concert Life in Eighteenth-Century Britain, ed. Susan Wollenberg and Simon McVeigh (Aldershot: Ashgate, 2004), 199-218.

16 Samuel Howard, An Anthem for Voices and Instruments (London, 1792), title page. The publisher of this edition is discussed below.

17 Fiske, 'Howard, Samuel'; Eggington, The Advancement of Music, 85 n.57.

18 Susan Wollenberg, Music at Oxford in the Eighteenth and Nineteenth Centuries (Oxford: Oxford University Press, 2001), 16 (and on Burney's D.Mus. in general, 15-19).

19 See Johnstone, 'Music and Drama at the Oxford Act of 1713'; also Susan Wollenberg, 'Music in $18^{\text {th }}$-Century Oxford', Proceedings of the Royal Musical Association 108/1 (1981-1982), 69-99; Wollenberg, Music at Oxford, especially Chapter 2, 'Music in an Academic Context, I', 8-34.
} 
apparent that this high frequency of performance was heavily reliant upon Howard's own participation, offering a neat illustration of the extent to which a middle-ranking professional musician in the capital could use academic recognition as a platform from which to raise his public profile considerably - even if this was not to last much beyond his own lifetime. Since relatively little is known of Samuel Howard's life, it seems appropriate to take this opportunity first to report upon what more has come to light in connection with his anthem and its context.

[Figure 1 near here, full page; caption in separate file]

\section{BIOGRAPHY}

Some aspects of Howard's life seem destined to remain mysterious: his date of birth, for example, reported by most authorities as 1710, has been described by Donald Burrows as surprisingly early for one who left the Chapel Royal as late as 1733 - by which time he would have been twenty-three. ${ }^{20}$ Unfortunately the name Samuel Howard is sufficiently common to make the simple searching of London baptismal records across the period $c .1700-1720$ all but futile as a method of pinpointing his precise origins. An entry on Howard in the Dictionnaire historique des musiciens of Alexandre-Etienne Choron and François-Joseph-Marie Fayolle (1810), however, describes him as 'docteur en musique à Londres, né dans cette ville vers 1718' (doctor of music at London, born there around 1718). ${ }^{21}$ This may not be reliable: the concluding remark that 'Le docteur Boyce, dans sa Cathedral music, nous a conservé plusieurs morceaux de sa composition' (Dr. Boyce, in his Cathedral Music, has preserved for us several pieces of his composition) is certainly incorrect - there is no music by Howard in Cathedral Music - and it seems likely that the editors misinterpreted a remark supplied by an English informant to the effect that Howard had acted as Boyce's assistant in compiling Cathedral Music. ${ }^{22}$ Moreover, Choron

\footnotetext{
20 Burrows, Handel and the English Chapel Royal, 447 n.37.

21 Alexandre-Etienne Choron and François-Joseph-Marie Fayolle, Dictionnaire historique des musiciens, volume I (Paris: Valade, 1810; repr. Hildesheim: Georg Olms, 1971).

${ }^{22}$ Howard's role as Boyce's assistant in the compilation of Cathedral Music is widely attested; see for example The Lady's Magazine, Tuesday 16 February 1779, 95-96, where William Hayes is named alongside Howard in a description of Boyce's funeral. Howard's music was unlikely, in fact, to have been included by Boyce in Cathedral Music, which extended only as far as the opening decades of the
} 
and Fayolle, or their English correspondent, could easily have reached the 1718 date by counting back from his departure from the Chapel Royal, much like Burrows. In the absence of further information, nevertheless, this account from within living memory of the composer's lifetime seems worthy of consideration.

By contrast, the widespread agreement about the date of Howard's death in 1782 is well supported by contemporary accounts. The Gentleman's Magazine reported his death on 13 July 1782 at his house in Norfolk Street, Strand, ${ }^{23}$ and as we have seen his burial nine days later is recorded in the registers of St Clement Danes church, where he was organist. This does, however, lead to a minor conundrum surrounding the identity of the publisher of 'This is the day', the resolution of which incidentally supplies a number of new biographical details.

An Anthem for Voices and Instruments . . by Dr Sam[ue]l Howard was entered into the registers at Stationers' Hall on 7 July 1792 by one Samuel Howard, ${ }^{24}$ despite the fact that Samuel the composer had by this point been dead almost exactly a decade. Clearly the publisher must have been a living relative; presumably the same individual who signed the title pages of each of the three copies I have inspected ' $\mathrm{S}$. R. Howard'. ${ }^{25}$ Indeed, a 'Samuel Reynolds Howard . . gent.' is recorded as living in Norfolk Street, Strand in October $1790 .^{26}$ The baptism of Samuel Reynolds Howard was recorded at St Clement Danes on 24 June 1760, giving his birth date as 29 May and listing his parents as Samuel and Mary; the same register lists a second son, James, in July 1761 and a daughter, Mary, the following July. It therefore seems clear that the publisher of the anthem in 1792 was the eldest child of the composer and his wife, Mary. Little else is known of Samuel Reynolds Howard, except that he was

eighteenth century (with music by Weldon, Clarke and Croft); neither, though, is any music by Howard included in Samuel Arnold's volumes under the same title, of 1790.

23 The Gentleman's Magazine, 1782, volume II, 359.

${ }^{24}$ Michael Kassler, Music Entries at Stationers' Hall, 1710-1818 (Aldershot: Ashgate, 2004). Copies seem to have been available to the public as early as 12 June; see The St James's Chronicle or the British Evening Post, 12-14 June 1792.

25 These are as follows: Cambridge, University Library, mus.11.8; London, British Library, g.502.(3.); London, Royal College of Music, d503.

${ }^{26}$ Records of the Sun Fire Office (insurers), London Metropolitan Archives, MS 11936/373/575109. 
apprenticed in 1776 to Thomas Gapper, attorney at law of the Inner Temple. ${ }^{27}$

The identification of Mary Howard as Samuel Reynolds Howard's mother adds useful information to the report of her death 'In Norfolk-street, Strand', in the Bath Chronicle and Weekly Gazette for 12 August 1790, where she is described simply as 'Mrs. Howard, relict of the late Samuel Howard, Mus. Doct.'. According to the register of burials for the City of London she was buried four days later at St Clement Danes, ${ }^{28}$ presumably alongside her husband. The couple's earlier marriage certificate also survives, dated 2 August 1759, in the Parish Register at Holy Trinity, Clapham. Here we learn both that Mary's maiden name was Reynolds (thus explaining the middle name they gave to their first son), and that the groom - whose identity is confirmed through his description as 'of the parish of St Clement Danes' was already a widower.

All this is notable because it appears to conflict with the information given towards the end of the otherwise informative and reliable entry on Samuel Howard the composer in the Biographical Dictionary of Actors, Actresses, Musicians . . . and Other Stage Personnel:

Administration of his estate was granted to his daughter Anna Howard of the parish of Kingsburg [sic], Middlesex. In that administration Samuel Howard was described as a widower. $^{29}$

I have so far been unable to find any trace of this administration, but even had his estate for some reason been entrusted to a child of a previous marriage, as Anna would have to have been, it would surely have been strange to describe Samuel as a widower on his death in 1782 if he left behind a living wife. It may also be relevant that the composer's large collection of manuscript and printed music seems to have remained at his house in Norfolk Street at least until 1792, to judge from the listing in

27 Register of Duties Paid for Apprentices' Indentures, 1710-1811; The National Archives, Kew, Board of Stamps: Apprenticeship Books, Series IR 1, 17 June 1776; accessed via <ancestry.com> (10 November 2016).

28 Middlesex, City of London Burials 1754-1855, Greater London burial index; accessed via $<$ findmypast.co.uk> (27 September 2016).

29 Philip H. Highfill, Kalman A. Burnim and Edward A. Langhans, A Biographical Dictionary of Actors, Actresses, Musicians, Dancers, Managers, and Other Stage Personnel in London, 1660-1800, volume 8: Hough to Keyse (Carbondale: Southern Illinois University Press, 1982), 3-4. 
the 1799 sale catalogue of no fewer than ten copies of the print of 'This is the day'. ${ }^{30}$ That aside, though there are several Howards who seem to have been connected with the parish of St Andrew, Kingsbury in Middlesex, no Anna (or Ann(e), or even Hannah) seems likely to have been a daughter born to Samuel before 1759. In the absence of the documentation described it seems logical to conclude that it relates to yet another, unconnected Samuel Howard.

Before returning to describe the events surrounding our Samuel Howard's receipt of the Cambridge doctorate, we might briefly take stock of his life up to that point. There had certainly been low points in his personal affairs, not least presumably the death of his first wife, and a rather nasty encounter with a highwayman in Lambeth in $1751 .{ }^{31}$ However, by the time of his second marriage he could look back on a modestly successful career as a composer for the theatre, with his best works handsomely printed under Royal Privilege. His prominence in the Academy of Ancient Music and his posts as organist at both St Bride's and St Clement Danes made him already a musician of some standing in the capital. But the high point of his career was to come towards the end of the $1760 \mathrm{~s}$.

\section{HOWARD'S MUS.D. AND THE INSTALLATION OF THE DUKE OF GRAFTON}

In the absence of information about the eighteenth-century statutory requirements for the award of Doctor in Music at Cambridge, ${ }^{32}$ we can learn most about the immediate circumstances of Howard's doctorate from the supplicat, or attestation on his behalf, submitted for the consideration of the Regents of the University by the College that presented him for his degree (see Figure 2 for a reproduction of the original): ${ }^{33}$

${ }^{30}$ Collection of Old Music ... Late the Property of Dr. Samuel Howard, Deceased, items 125-134, pages $9-10$.

31 Derby Mercury, Friday 13 September 1751: 'On Wednesday Night, about Six o'Clock, Mr. Samuel Howard, of St. Clement's Danes, was robbed by a single Highwayman, well mounted on a dark-brown Horse, of Two Guineas and a Half, and some Silver, on this Side [of] the old Turnpike at Lambeth. There were three or four Persons on Foot within five Yards of the Highwayman.'

32 Eggington, The Advancement of Music, 59-60; on the requirements at Oxford, see Wollenberg, Music at Oxford, 13-15.

${ }^{33}$ Cambridge University Archives, Supplicats for Degrees, Supplicats 67 (1768-1769), item 101. I thank Ralph Hawtrey for his improvements to several details of my translation of this document. Johnstone transcribes the similarly worded supplicat for Greene's 1730 doctorate; see Johnstone, 'The Life and Work of Maurice Greene', 118. 


\section{King's College}

Samuel Howard begs Your Reverences that his twelve years of study in the science of Music, together with its constant practice and the highest approbation of that Faculty, be considered sufficient to warrant his initiation into the same Faculty; accordingly, he shall compose a Musical Work to be solemnly sung before you in the Church of the Blessed [Virgin] Mary.

Joah Bates, Praelector

Read and approved 27 June 1769

\section{[Figure 2 near here, full page-width; caption in separate file]}

A number of aspects of this supplicat invite further comment. Howard's matriculation or enrolment at King's College is perhaps to be expected: the Professor of Music at Cambridge was commonly organist at King's, and the incumbent of both posts in 1769 was Dr John Randall, who had been a slightly younger contemporary of Howard's as a Chapel Royal boy (it was Randall who took the part of Esther for Gates's 1732 production, in which Howard sang tenor). ${ }^{34}$ No less worthy of note is the identity of the Praelector at King's (an office which carried - and still carries - the responsibility for the official presentation of members of College for their degrees), who was none other than Joah Bates, later director of the London Concerts of Antient Music from their inception in 1776, and a key instigator of the 1784 Handel Commemoration at Westminster Abbey. ${ }^{35}$

It might be thought surprising that Howard professed to only twelve years of study in 1769 , though in fact this length of time probably reflects the usual expectation of the University rather than any attempt to evaluate the composer's actual experience. Perhaps more curious is Bates's choice not to refer to Howard's doctorate directly but rather to allude to it by calling for his admission to the Faculty of Music, a body which could not then be said to exist in any formal sense. ${ }^{36}$ In this too it may be that he was

${ }^{34}$ Burrows, Handel and the English Chapel Royal, 288-289, 575; Christopher Hogwood, 'Randall, John', Grove Music Online (11 November 2016).

35 See Betty Matthews, 'Joah Bates: A Remarkable Amateur', Musical Times, 126 (1985), 749-753. Owain Edwards and William Weber ('Bates, Joah', Grove Music Online, consulted 11 November 2016) state that Bates did not become a fellow of King's until 1770, the year following this evidence that he was already acting as Praelector in 1769; be that as it may, his association with the college went back as far as his matriculation in 1760, graduating BA in 1764 and MA in 1767.

${ }^{36}$ For a useful if informal summary of the history of academic study of music at Cambridge, see Martin Cullingford, 'A Degree of Harmony', published on the Cambridge Music Faculty website at $<$ http://www.mus.cam.ac.uk/about-us/CambridgePast.pdf $>$ (consulted 11 November 2016). 
following a standard form of words, here derived from the supplications of candidates in the fields of medicine, law and divinity, whose doctorates (unlike the Mus.D.) followed a period of formal study and entitled their recipients to sit in Congregation.

Finally, the use of the verb 'to compose' (compono) alone in the description of the promised future performance would seem to imply a gap of some time, were it not for an unequivocal statement in the Public Advertiser that Howard's anthem 'This is the day' was indeed performed at Great St Mary's, the University Church, on Sunday 2 July 1769 , and that this was his doctoral exercise (Figure 3 ). ${ }^{37}$ Perhaps, then, we are to interpret this word to cover all aspects of the 'bringing together' of the work - which must surely have already been 'composed', as we understand it (at least in large part) by Tuesday 27 June - up to and including its practical performance. This is an attractive idea given Howard's later prominence as a conductor, to be discussed in the concluding section of this paper. In any case, it is now possible to confirm that the anthem was composed for his doctorate, which was duly awarded the following Tuesday. ${ }^{38}$

\section{[Figure 3 near here, half(?) page-width; caption in separate file]}

The notice in the Public Advertiser on 4 July also calls attention to the presence of Augustus Henry FitzRoy, third Duke of Grafton, at the performance of 'This is the day', and thereby to Howard's role in the festivities surrounding the installation of the Duke as Chancellor of the University at Commencement that year. Indeed, the previous issue of the Public Advertiser had carried a rather fuller account of the events of that weekend, with some detailed musical references. ${ }^{39}$ On his arrival at Senate House from Trinity College on the Saturday, his Grace would be greeted by 'a short Overture' from the Band of Music; the formal part of the Installation being over, 'The Installation Ode will then be performed in the Music Gallery under the Direction of Dr. Randall, the

\footnotetext{
37 Public Advertiser, Tuesday 4 July 1769.

38 St James's Chronicle or the British Evening Post, 6-8 July 1769; Middlesex Journal or Chronicle of Liberty, 8-11 July 1769, Public Advertiser, 10 July 1769. The London Chronicle, 29 June-1 July 1769 , apparently uniquely, reports the same event a week earlier on 27 June, but given the widespread agreement elsewhere as to the sequence of events this seems most likely to be a garbled reference to the date of the Regents' concession or acceptance of the relevant supplications, as visible beneath Bates's attestation for Howard (Fig.3).

39 Public Advertiser, Saturday, 1 July 1769; see also the similar report in the Whitehall Evening Post or London Intelligencer, 29 June-1 July 1769.
} 
Professor'; ${ }^{40}$ then followed a procession back to Trinity, where the Duke would be 'received into the Great Hall with Flourish of Trumpets and Kettle Drums'. After dinner, Handel's Acis and Galatea was given at the Duke's expense at the Senate House.

The next morning, Sunday, the Chancellor was to 'attend Divine Service at St. Mary's Church, when Purcell's Te Deum will be sung' in the course of the Commemoration of Founders and Benefactors of the University. Then 'in the Afternoon his Grace goes to St. Mary's, when the Sermon is preached by Dr. Proby ... and then follows Dr. Howard's new Anthem from the 118th Psalm, "This is the Day which the Lord hath made, \&c.",

The last time such extravagant musical events had been witnessed in Cambridge had been in 1749, at the installation of the new Chancellor's predecessor, the Duke of Newcastle, when William Boyce had been engaged to provide the music and rewarded with a doctorate for his anthem 'O be joyful'. Boyce set to music the Installation Ode on that occasion, ${ }^{42}$ 'Here all thy active fires diffuse', to a text by William Mason; he also conducted over a hundred singers and instrumentalists from the London choirs and theatres in performances of four other major works of his own, in what amounted to 'a virtual four-day festival devoted to [his] music'. ${ }^{43}$

Given Boyce's prominent role in the 1749 festivities, it is tempting to speculate that he was again approached in connection with the events of 1769 , this time passing on the commission to his assistant Samuel Howard. However, as noted above, the presence of John Randall in Cambridge provides no less plausible a route by which he could have been enlisted. Moreover, the specific items mentioned in the Public

${ }^{40}$ Randall's Installation Ode set a text by Thomas Gray (see below) that was originally to have been set by Charles Burney; when the arrangement foundered over Burney's expensive plans for the orchestra, he submitted instead for the Oxford D.Mus., receiving the degree that same year, the week before the Cambridge Installation ceremony. See Roger H. Lonsdale, Dr. Charles Burney: A Literary Biography (Oxford: Clarendon, 1965), 77-78.

41 In fact the text is assembled from a number of Psalm verses, all as given in the 1669 Book of Common Prayer: Ps.118, v.24; Ps.145, vs.3; Ps.46, vs.9 and Ps.68, vs.6; Ps.89, vs.9, and Ps.86, vs.8; Ps.89, vs.15; Ps.86, vs.9 and Ps.138, vss.5, 2.

42 General Advertiser, 1 July 1749.

43 Ian Bartlett and Robert J. Bruce, William Boyce: A Tercentenary Sourcebook and Compendium (Newcastle upon Tyne: Cambridge Scholars, 2011), 59; for a fuller account of Boyce's role in the 1749 installation see pages 58-63. 
Advertiser's account of the weekend align the 1769 installation closely with a particular taste for Ancient Music and Handelian oratorio that we might equally associate with the involvement of Joah Bates, and which represented native habitat for a musician like Howard with his connections in the Academy of Ancient Music. The Installation Ode itself requires separate comment, but Acis and Galatea was a clear favourite in this environment (according to William Weber, the most popular of all Handel's large-scale English-language works in the flourishing provincial festivals), while Purcell's Te Deum - presumably here in Boyce's later reworking - had been among the first 'classics' of the repertoire. ${ }^{44}$ And although Howard's anthem was newly composed, we have already seen that it self-consciously adopted many features associated with the trend for 'Ancient Music'. If the 1749 installation had amounted to a festival of Boyce's music, the events of July 1769 represent a Cambridge equivalent of the thriving provincial festivals found in Salisbury, Oxford or Worcester (and its Three Choirs neighbours, Hereford and Gloucester) - exactly the same festival culture, with its attendant links with the older Ancient Music and oratorio traditions, within which Howard and his anthem were to feature prominently in the coming decade.

Within this context, Randall's setting of the Installation Ode by Thomas Gray is perhaps less out of place than it may seem. Regrettably the music does not survive, but the text was published and has been widely reprinted and anthologized. ${ }^{45}$ We have nevertheless a fascinating recollection published among the Cantabrigiana anonymously contributed to The Monthly Magazine by the Cambridge poet and classicist George Dyer (1755-1841): ${ }^{46}$

XLIV. - DR. RANDALL'S MUSIC to the ODE on the INSTALLATION of the DUKE of GRAFTON.

${ }^{44}$ William Weber, The Rise of Musical Classics in Eighteenth-Century England: A Study in Canon, Ritual, and Ideology (Oxford: Oxford University Press, 1992), 127 (Acis \& Galatea), 111-17 (Purcell Te Deum); on Boyce's version of Purcell's Te Deum see also Rebecca Herissone, 'Performance History and Reception', in The Ashgate Research Companion to Henry Purcell, ed. Herissone (Farnham: Ashgate, 2012), 303-351 at 326-327.

45 Thomas Gray, Ode Performed in the Senate-House at Cambridge, July 1, 1769, at the Installation of his grace Augustus-Henry Fitzroy, Duke of Grafton, Chancellor of the University. Set to Music by Dr. Randal (Cambridge: J. Archdeacon, 1769). For a useful bibliography and anthology of related writings see the relevant pages of David Hill Radcliffe, English Poetry 1579-1830: Spenser and the Tradition, $<$ http://spenserians.cath.vt.edu/TextRecord.php?textsid=34777> (accessed 21 November 2016).

46 The Monthly Magazine, or British Register, 15/4 (April 1, 1803), 236. 
Gray's Ode on the Installation of the Duke of Grafton possesses great poetical beauties, and would have been more admired had it not been surpassed by his two master-pieces, the Bard, and the Progress of Poetry. It was set to music by Dr. Randall, Professor of Music at the time, and a very skilful organist. The Doctor, while composing it, regularly attended Gray for three months. Gray himself possessed a very accurate taste in music, had a very high opinion of musical expression, and weighed every note of the composition with the most critical exactness, that it might forcibly express his language and sentiments. Gray, having formed his taste after the Italian school, was no friend to the noise of some great composers. The music therefore is formed rather on the Italian taste; but when the Doctor came to the chorus, Gray exclaimed - "I have now done. - Make as much noise as you please."

The score of this music in manuscript is still possessed by the Doctor's son, Mr. Edw. Randall, who resides in the town; and it is wished and expected that it will still be published, it having been suggested to him, that it would doubtless prove highly acceptable to persons of taste, and lovers of harmony. A sacrifice ought to be offered to the Muses for delaying the publication so long:

For they are ladies of the sweetest nature;

But, if neglected, will become indignant.

Dyer did not matriculate at Emmanuel College until 1774, so it is unclear whether he would have witnessed the performance of the Ode first-hand - though as a scholar of Christ's Hospital for seven years already by 1769 , it is not inconceivable that he could have been present, aged fifteen, for the weekend's festivities in Cambridge. ${ }^{47}$ Be that as it may, Dyer's long subsequent career in the University undoubtedly made him well placed to discover this sort of anecdotal information at close hand. His final paragraph perhaps offers an insight into the process by which Samuel Reynolds Howard was prevailed upon to bring his father's anthem into print in 1792, though ultimately in Randall's case it was rather less successful. ${ }^{48}$

Gray's aversion to 'noise', one imagines, may not have predisposed him towards the massive choruses of Howard's 'This is the day' when it was performed the day after his ode, but in other respects his taste, while Italianate, represents a particular subset of the 'Ancient' style that dominated the musical celebration of the Installation. As Weber points out, Gray and other literary contemporaries founded a cult-like

\footnotetext{
47 See Nicholas Roe, 'Dyer, George (1755-1841), ODNB Online (accessed 21 November 2016).

48 Despite Dyer's assurance that the score of Gray's ode still existed in 1803, there is no mention of the score in Edward Randall's will at the National Archives, proved 18 January 1841 (PRO, Prob11/1940, pp.46-48); the only musical reference concerns the bequest of his copies of the Histories of Burney and Hawkins to his daughter.
} 
admiration of Giovanni Battista Pergolesi (1710-36), whose music would later feature prominently in the repertoire of the Concerts of Antient Music under Joah Bates's direction: after Handel and Purcell, only Johann Adolph Hasse (1699-1783) would be performed more frequently. ${ }^{49}$

The unusual details of the working relationship between Randall and Gray given in Dyer's account are of particular interest, not only for the closeness of their collaboration over what seems an extraordinary amount of time for a comparatively short work - assuming it began with a symphony, the Ode would have comprised ten movements, of which four were recitative - but also for the apparent extent of Gray's interest in and influence upon the details of Randall's setting. This input seems to have extended well beyond the process of composition, as Joseph Cradock recounts in his memoirs:

The pleasantest morning that I passed at Cambridge, was in company with Mr. Gray, and some critics, at the rehearsal of the music for his Ode, previous to its grand performance at the Senate House; and I thought that as he had so many directions to give, and such nice distinctions to make, it was well he had to deal with the pliant Dr. Randall, rather than with some of the very able composers in the metropolis. ${ }^{50}$

A further account of the rehearsals for the ode comes from a letter by Gray himself to Norton Nichols, in which we gain an idea of the strength of the performing resources that must have been available in Cambridge that weekend:

My Ode has been rehearsed again and again, and the scholars have got scraps by heart: I expect to see it torn piece-meal in the North-Briton before it is born. If you come you shall see it, and sing in it amidst a chorus from Salisbury and Gloucester music meeting, great names there, and all well versed in Judas Maccabaeus. I wish it were once over; for then I immediately go for a few days to London, and so with Mr. Brown to Aston, though I fear it will rain the whole summer, and Skiddaw will be invisible and inaccessible to mortals. ${ }^{51}$

Gray was clearly uncomfortable with the attention - and, as his reference to the

49 Weber, The Rise of Musical Classics, 178 and Appendix; on Pergolesi's earlier prominence in the concerts of the Academy of Ancient Music, see Eggington, The Advancement of Music, 100-101.

50 Quoted in The Poetical Works of Thomas Gray, ed. John Bradshaw (London: Bell, 1891), 297.

${ }^{51}$ Gray to Nicholls, 24 June 1769; printed in The Poems of Mr. Gray. To which are prefixed Memoirs of his Life and Writings, ed. William Mason (York: Ward, 1775), 347. 
mountain of Skiddaw reveals, keen to head north to the Lake District. His dislike for musical bombast is again on display here in his scornful reference to the chorus's familiarity with Judas Maccabeus: Gray was no Handelian, as Cudworth pointed out. ${ }^{52}$ But the presence of the Salisbury and Gloucester choruses is nevertheless revealing, since it implies an ensemble of considerable numbers. Assuming, as seems reasonable, that the same singers were involved in the performances of Purcell's Te Deum and Jubilate and Howard's 'This is the Day' the following day, we may speculate that Howard's anthem was originally given by a group considerably larger than the seventy or so performers - roughly evenly divided between singers and instrumentalists typical of the performances of the Academy of Ancient Music in the 1780s and 1790s. ${ }^{53}$ Presumably the players came mainly from London, as they had done for Boyce's music in 1749 .

Howard's involvement in the music-making surrounding the 1769 Installation, together with the concomitant award of his doctorate, was a high point of his professional life. As we shall see, his conducting career and, with it, 'This is the day', were to retain their lustre over at least the coming decade. One particular event deserves immediate attention, since it too associates Howard with the academic establishment that seems to have so bolstered his career at this later stage of his life. This is a performance of the anthem in Oxford in July 1777 that, together with the 1769 Cambridge performance, explains the reference to performance in 'the Two Universities' on the title page of the 1792 print.

The occasion for this 1777 performance was another extended musical event not unlike that at Cambridge in 1769, and connected to the annual Commemoration of Founders and Benefactors to the University. ${ }^{54}$ The musical events of the week began with the performance - at St Mary's Church, on Wednesday 2 July - of Handel's 'Dettingen' Te Deum, together with 'the Old Hundredth psalm' and a new anthem by 'Mr. Hayes', at the anniversary meeting of the governors of and contributors to the Radcliffe Infirmary. ${ }^{55}$ This must have been Philip Hayes, who was only to receive his

\footnotetext{
52 Charles Cudworth, 'Thomas Gray and Music', Musical Times 112 (1971), 646-648.

53 See for example the programme for Thursday 12 February 1789, which details about thirty-five singers (depending on the number of 'Dr. Cooke's [Westminster Abbey] Boys' in attendance) and thirty-six instrumentalists.

54 St James's Chronicle or the British Evening Post, 5-8 July 1777 (for example).

55 St James's Chronicle, 5-8 July 1777
} 
doctorate on 6 November. ${ }^{56}$ The evening of the same day 'the oratorio of Providence was performed in the Theatre to a very crouded audience, for the benefit of the charity' ${ }^{57}$ this was the first of three performances of this work in the same week (the remaining two following on Thursday afternoon and Friday), which led up to the simultaneous awards of Bachelor and Doctor of Music on the Saturday for its composer, the London violinist John Abraham Fisher (1744-1806) ${ }^{58}$ In addition to all this, Thursday evening saw performances of Acis and Galatea and 'the Coronation Anthem' ('Zadok the Priest'?) as part of what is described as 'the choral music for the term'.

The place of Howard's 'This is the day' in this sequence of events is somewhat ambiguous. It may have formed part of the annual Commemoration itself on the Thursday, which was given 'with the usual ceremonies'; speeches were given, and a number of individuals admitted to honorary degrees, while 'Samuel Howard, Doctor of Music, of King's College, Cambridge, was admitted ad eundem' ${ }^{59}$ Music by Howard was certainly performed at some point during the week, and the venue must have been the Sheldonian Theatre to judge from a remark printed in the Morning Chronicle and London Advertiser:

Dr. Howard, of Norfolk-Street, Strand, was last week admitted ad eundem at Oxford. His composition was applauded at the Theatre much beyond any of the other Authors. ${ }^{60}$

The reference on the later title page of 'This is the Day', together with the fact that no other surviving work by Howard would have been remotely suitable for such an occasion, makes it all but certain that the orchestral anthem is the composition referred to here. Perhaps the 'other Authors' referred to here are those of the literary compositions for the Chancellor's prizes, which were also read on the same occasion one can certainly imagine the anthem receiving the more enthusiastic response in such

${ }^{56}$ Simon Heighes, The Life and Work of William and Philip Hayes (New York: Garland, 1995; repr. Abingdon: Routledge, 2013), 53.

57 Gazetteer and New Daily Advertiser, 5 July 1777.

58 Gazetteer and New Daily Advertiser, 5 July 1777; St James's Chronicle or the British Evening Post, 5-8 July 1777.

59 St James's Chronicle or the British Evening Post, 5-8 July 1777.

${ }^{60}$ Morning Chronicle and London Advertiser, 8 July 1777. 
circumstances. An ad eundem degree was effectively an honorary recognition by the awarding institution of the recipient's status in the other University; Benjamin Cooke, Howard's younger contemporary in the Academy of Ancient Music, was also to hold doctorates from both Universities by the same mechanism, and Maurice Greene had earlier incorporated his Cambridge Mus.D. at Oxford in $1735 .{ }^{61}$ Unlike for Greene, who 'already held every major musical appointment in the land', ${ }^{62}$ the prospect of further advancement no doubt enhanced the prestige of holding concurrent doctorates from both Universities. At the same time, it is possible that Howard played some practical role alongside the other London performers who accompanied Fisher to Oxford for the week's events. ${ }^{63}$ As we shall see from the brief survey of other documented performances of Howard's orchestral anthem during his lifetime that follows, the notion here of Howard's presence in Oxford leading to a fresh performance of 'This is the day' would fit well with the pattern of his activities that emerged during the 1770 s as a whole.

\section{PERFORMANCES OF 'THIS IS THE DAY', 1769-1782}

Apart from the two University performances, the wording of Samuel Reynolds Howard's title page in 1792 proudly declared that the anthem had been heard 'At St. Margaret's Church, before the Governors of the Westminster Infirmary; . . . and upon many other Public Occasions in different parts of the Kingdom'. In fact the anthem was given no fewer than eighteen times between Howard's Cambridge excursion of 1769 and his death in 1782 (see Table 1), and up to five more if one includes the private rehearsals typically given by the Academy of Ancient Music the week before their

${ }^{61}$ Eggington, The Advancement of Music, 60; Johnstone, 'The Life and Work of Maurice Greene', $118-125$.

62 Johnstone, 'The Life and Work of Maurice Greene', 125.

63 Gazetteer and New Daily Advertiser, 5 July 1777: ‘A very numerous band, both vocal and instrumental, were provided. Mrs [Margaret] Farrel [later Kennedy; d.1793], first singer, from Ranelagh, was much admired; as were likewise Miss Mahon [Elizabeth(?), $b$. late 1750s; or one of her sisters], Mess. Nares [presumably not the organist and composer, who had been a Mus.D. of Cambridge since 1757] and [John?] Mathews, \&c. The instrumental part was led by Mr. Fisher.' 


\section{[Table 1 Known performances of Howard's 'This is the day which the Lord hath made']}

\begin{tabular}{|c|c|c|c|c|c|}
\hline Date & Organisation & Vепие & Named personnel & Notes, other items & Source \\
\hline $\begin{array}{l}\text { Sunday } \\
2 \text { July } 1769\end{array}$ & $\begin{array}{l}\text { University of } \\
\text { Cambridge }\end{array}$ & $\begin{array}{l}\text { Great St Mary's, } \\
\text { Cambridge }\end{array}$ & $\begin{array}{l}\text { 'a chorus from Salisbury and } \\
\text { Gloucester music meeting' } \\
\text { (Gray; see above) }\end{array}$ & $\begin{array}{l}\text { Also performed the same weekend: Purcell, Te Deum } \\
\text { and Jubilate; Randall, Installation Ode for the Duke } \\
\text { of Grafton; Handel, Acis and Galatea }\end{array}$ & [See above] \\
\hline Tuesday 3 April & Westminster & St Margaret's & & Corelli, concerto op.6 no. 8; Handel, Dettingen Te & Lloyd's Evening Post, 19- \\
\hline 1770 & $\begin{array}{l}\text { Hospital } \\
\text { trustees }\end{array}$ & $\begin{array}{l}\text { Church, } \\
\text { Westminster }\end{array}$ & & Deum, 'Coronation Anthem' (unspecified) & 21 March 1770 \\
\hline $\begin{array}{l}\text { Thursday } \\
3 \text { January } 1771\end{array}$ & $\begin{array}{l}\text { Academy of } \\
\text { Ancient Music }\end{array}$ & $\begin{array}{l}\text { The Crown and } \\
\text { Anchor, Strand }\end{array}$ & & Additionally rehearsed the previous week & F-Pn, MS Rés. F. 1507 \\
\hline $\begin{array}{l}\text { Thursday } \\
28 \text { March } 1771\end{array}$ & $\begin{array}{l}\text { Academy of } \\
\text { Ancient Music }\end{array}$ & $\begin{array}{l}\text { The Crown and } \\
\text { Anchor, Strand }\end{array}$ & & $\begin{array}{l}\text { The Academy's annual 'Publick night', upon which } \\
\text { ladies were admitted to the 'great room' (being } \\
\text { usually confined to the gallery); additionally } \\
\text { rehearsed the previous week }\end{array}$ & F-Pn, MS Rés. F. 1507 \\
\hline $\begin{array}{l}\text { Tuesday } 9 \text { April } \\
1771\end{array}$ & $\begin{array}{l}\text { Westminster } \\
\text { Hospital } \\
\text { trustees }\end{array}$ & $\begin{array}{l}\text { St Margaret's } \\
\text { Church, } \\
\text { Westminster }\end{array}$ & & $\begin{array}{l}\text { Corelli, concerto op. } 6 \text { no. } 8 \text {; Handel, Dettingen Te } \\
\text { Deum, Coronation Anthem 'My Heart is inditing' }\end{array}$ & $\begin{array}{l}\text { Public Advertiser, } 25 \\
\text { March } 1771\end{array}$ \\
\hline
\end{tabular}




\begin{tabular}{|c|c|c|c|c|c|}
\hline Date & Organisation & Vепие & Named personnel & Notes, other items & Source \\
\hline $\begin{array}{l}\text { Thursday } \\
25 \text { July } 1771\end{array}$ & $\begin{array}{l}\text { Three Choirs } \\
\text { Festival }\end{array}$ & $\begin{array}{l}\text { Hereford } \\
\text { Cathedral }\end{array}$ & $\begin{array}{l}\text { Singers 'the two Miss } \\
\text { Linley's', Messrs Norris, } \\
\text { Mathews; 'The band to be led } \\
\text { by Signor Degiardini'. }\end{array}$ & $\begin{array}{l}\text { Handel, Dettingen Te Deum and Jubilate, } \\
\text { 'Coronation Anthem' (unspecified); also performed } \\
\text { that week: Handel, Esther, Messiah; Purcell, Te } \\
\text { Deum and Jubilate; Boyce, 'An Anthem' } \\
\text { (unspecified); Arnold, The Cure of Saul (sacred ode); } \\
\text { various smaller vocal and instrumental works }\end{array}$ & $\begin{array}{l}\text { London Evening Post, 3-6 } \\
\text { August } 1771\end{array}$ \\
\hline Tuesday & Westminster & St Margaret's & & 'An overture' (unspecified); Handel, Dettingen Te & Gazetteer and New Daily \\
\hline 7 April 1772 & $\begin{array}{l}\text { Hospital } \\
\text { trustees }\end{array}$ & $\begin{array}{l}\text { Church, } \\
\text { Westminster }\end{array}$ & & Deum; Cooke, 'An Anthem’ (unspecified) & Advertiser, 24 March 1772 \\
\hline $\begin{array}{l}\text { Thursday } \\
18 \text { March } 1773\end{array}$ & $\begin{array}{l}\text { Academy of } \\
\text { Ancient Music }\end{array}$ & $\begin{array}{l}\text { The Crown and } \\
\text { Anchor, Strand }\end{array}$ & & Additionally rehearsed the previous week & F-Pn, MS Rés. F. 1507 \\
\hline $\begin{array}{l}\text { Thursday } \\
21 \text { April } 1774\end{array}$ & $\begin{array}{l}\text { Westminster } \\
\text { Hospital } \\
\text { trustees }\end{array}$ & $\begin{array}{l}\text { St Margaret's } \\
\text { Church, } \\
\text { Westminster }\end{array}$ & & $\begin{array}{l}\text { Handel, Occasional Oratorio (overture), Dettingen } \\
\text { Te Deum, 'Coronation Anthem' (unspecified) }\end{array}$ & $\begin{array}{l}\text { Morning Chronicle and } \\
\text { London Advertiser, } 4 \\
\text { March } 1774\end{array}$ \\
\hline $\begin{array}{l}\text { Thursday } \\
21 \text { April } 1774\end{array}$ & $\begin{array}{l}\text { Academy of } \\
\text { Ancient Music }\end{array}$ & $\begin{array}{l}\text { The Crown and } \\
\text { Anchor, Strand }\end{array}$ & & $\begin{array}{l}\text { Cooke, 'How sleep the Brave' and 'In the merry } \\
\text { month of May' (glees); Purcell, The Loves of Dido } \\
\text { and Aeneas; Francesco Negri, Gloria in Excelsis Deo; } \\
\text { 'Non nobis Domine' (wrongly attrib. Byrd). } \\
\text { Presumably rehearsed the previous week. }\end{array}$ & $\begin{array}{l}\text { Printed wordbook (London, } \\
\text { 1774) } \\
\text { [US-SM Dev 8vo 80; also } \\
\text { Lbl, Ob, US-NYp and US- } \\
\text { BAu] }\end{array}$ \\
\hline
\end{tabular}




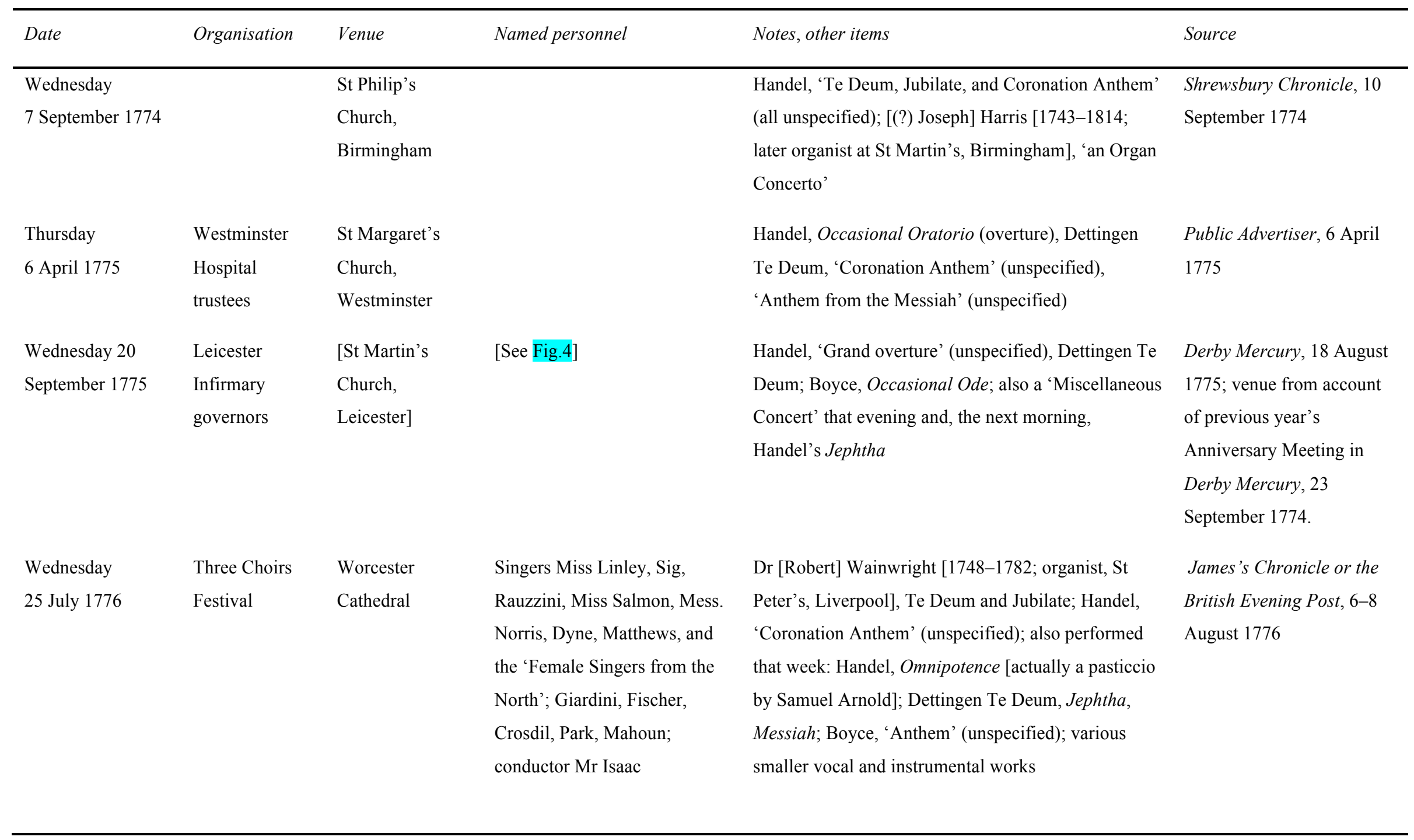




\begin{tabular}{|c|c|c|c|c|c|}
\hline Date & Organisation & Venue & Named personnel & Notes, other items & Source \\
\hline $\begin{array}{l}\text { Thursday } 27 \\
\text { March } 1777\end{array}$ & $\begin{array}{l}\text { Academy of } \\
\text { Ancient Music }\end{array}$ & $\begin{array}{l}\text { The Crown and } \\
\text { Anchor, Strand }\end{array}$ & & $\begin{array}{l}\text { Boyce, Solomon; Wilbye, 'Lady, when I behold the } \\
\text { roses' (madrigal); 'Non nobis Domine' (attrib. Byrd). } \\
\text { Presumably rehearsed the previous week. }\end{array}$ & $\begin{array}{l}\text { Printed wordbook (London, } \\
\text { 1777) } \\
\text { [Lfom 7/E/ACADEMY] }\end{array}$ \\
\hline $\begin{array}{l}\text { (?) Thursday } \\
3 \text { July } 1777\end{array}$ & $\begin{array}{l}\text { University of } \\
\text { Oxford }\end{array}$ & St Mary's Church & $\begin{array}{l}\text { (Probably) singers Mrs Farrel, } \\
\text { Miss Mahon, Messrs Nares } \\
\text { and Mathews; J. A. Fisher } \\
\text { (violin); conducted by Philip } \\
\text { Hayes }\end{array}$ & $\begin{array}{l}\text { Also performed that week: Handel, Dettingen Te } \\
\text { Deum, Acis and Galatea, 'Coronation Anthem' } \\
\text { (unspecified); Philip Hayes, 'Anthem' (unspecified); } \\
\text { Fisher, Providence (oratorio) }\end{array}$ & $\begin{array}{l}\text { See above; also Public } \\
\text { Advertiser, } 14 \text { June } 1777\end{array}$ \\
\hline $\begin{array}{l}\text { Wednesday } \\
9 \text { September } 1778\end{array}$ & $\begin{array}{l}\text { Three Choirs } \\
\text { Festival }\end{array}$ & $\begin{array}{l}\text { Gloucester } \\
\text { Cathedral }\end{array}$ & $\begin{array}{l}\text { Singers Miss Harrop, Miss } \\
\text { Salmon, Master Harrison, } \\
\text { Messrs Price, Norris and } \\
\text { Mathews; La Motte (violin) } \\
\text { Cervetto (cello), Fischer } \\
\text { (oboe). Conductor Mr Isaac }\end{array}$ & $\begin{array}{l}\text { Purcell/Boyce, Te Deum and Jubilate; Handel, } \\
\text { 'Coronation Anthem' (unspecified). Also performed } \\
\text { at other times that week: Handel, Dettingen Te Deum } \\
\text { and Jubilate, Esther (Acts } 1 \text { and 2), L'Allegro and Il } \\
\text { Penseroso (only), Messiah; Boyce, 'Anthem' } \\
\text { (unspecified); various smaller vocal and instr. works }\end{array}$ & $\begin{array}{l}\text { Gazetteer and New Daily } \\
\text { Advertiser, } 19 \text { August } 1778\end{array}$ \\
\hline $\begin{array}{l}\text { Thursday } \\
30 \text { August } 1781\end{array}$ & $\begin{array}{l}\text { Three Choirs } \\
\text { Festival }\end{array}$ & $\begin{array}{l}\text { Gloucester } \\
\text { Cathedral }\end{array}$ & $\begin{array}{l}\text { Singers Signora Prudom, Miss } \\
\text { Abrams, Master Clarke, Mess. } \\
\text { Norris, Harrison, Price, Walton } \\
\text { and Matthews. } \\
\text { Instrumentalists: Messrs } \\
\text { Cramer, Fischer, Crosdil and } \\
\text { Mahon. Conductor Mr. Isaac }\end{array}$ & $\begin{array}{l}\text { Handel, Dettingen Te Deum, 'Coronation Anthem' } \\
\text { (unspecified); other works performed that week: } \\
\text { Purcell/Boyce, Te Deum and Jubilate; Boyce, } \\
\text { 'Anthem' (unspecified); Handel, Joshua, Messiah; } \\
\text { Arnold, The Prodigal Son (oratorio); various smaller } \\
\text { vocal and instrumental works }\end{array}$ & $\begin{array}{l}\text { St James's Chronicle or the } \\
\text { British Evening Post, 7-9 } \\
\text { August } 1781\end{array}$ \\
\hline
\end{tabular}


semi-public 'Academy Nights'. ${ }^{64}$ Aside from the established 'classics' by Handel Messiah, Judas Maccabaeus, Acis and Galatea; the Coronation Anthems and Dettingen Te Deum and Jubilate - together with Purcell's D major Te Deum and Jubilate and perhaps Boyce's Solomon, it would be difficult to think of a single work that was performed on so many occasions. ${ }^{65}$

It should be remembered that this was a festival culture that strongly privileged the repeat performance of recognized canonic works: ${ }^{66}$ at the annual Festival of the Sons of the Clergy at St Paul's, Purcell's Te Deum and Jubilate (and later Handel's settings) were ritually performed year after year, while at the Three Choirs meetings, most extremely, Messiah was performed every year for two centuries beginning in the mid-eighteenth. While most such events featured newly composed music alongside the regular items, it was rare for these to maintain a place in the repertoire in future years. How, then, was Howard so successful in carving out a space for the repeated performance of his magnum opus? The answer seems to lie in the skilful way in which he built upon and exploited the contacts built up in the course of his career to date: his status as a respected London organist and leading member of the Academy of Ancient Music, and a wider exposure to performers and patrons from the provinces in connection with his short trip to Cambridge in July 1769.

Not surprisingly, given its prominence on the 1792 title page, the Anniversary Sermon at St Margaret's Church for the trustees of the Westminster Infirmary seems to have been the occasion for the most performances of the anthem in the years immediately after its Cambridge premiere: it was featured there every year between 1770 and 1775 inclusive, except for 1773 when an all-Handel programme was presented. ${ }^{67}$ The advertisements for these years do not provide details of performers or

${ }^{64}$ On this pattern of rehearsal and performance at the Academy see Eggington, The Advancement of Music, 78-80. It should be noted that, as in the case of the 1777 Oxford performance, very few of the sources listed in Table 1 identify Howard's anthem fully by its incipit ('an Anthem, by Dr. Howard' being the typical formulation); while this kind of listing frequently proves problematic when trying to identify a specific anthem by Handel or Boyce in the advertisements, the situation is much clearer with Howard, who is only known to have composed one such work.

65 Another exception should be made for the extraordinary popularity at the Academy of Ancient Music (and the later Concerts of Antient Music) of a Gloria in Excelsis Deo by one Francesco Negri; see Johnstone, 'Westminster Abbey and the Academy of Ancient Music', 348-350.

66 See for example Weber, The Rise of Musical Classics, 103-118.

67 St James's Chronicle or British Evening Post, 20-23 March 1773. 
the identity of the musical director, as they do for the years around 1780 - by which time Benjamin Cooke had become established as a regular conductor, and the event evolved into an annual presentation of Messiah. Given Cooke's role as director at the Academy of Ancient Music, it seems likely that this reflected a longstanding arrangement between the two organisations, and thus that the reason for the regular inclusion of 'This is the day' at the services in the early 1770s was because Howard was himself directing the music in these years. Indeed, there was even one occasion (21 April 1774) on which 'This is the day' was performed twice on the same day: at the11:30 service in Westminster, and then at the Academy's regular meeting at 7:00 the same evening. While there is no reason in principle why the two performances could not have happened entirely separately, it seems reasonable to suppose that a large number of the performers, Howard included, might have been involved in both events. It may even be relevant in this regard that the Westminster Infirmary's annual postservice dinners in 1770 and 1771 were taken not at the usual venue, the King's Arms in New Palace Yard, but at the Crown and Anchor in the Strand, where the Academy of Ancient Music held its regular meetings - and opposite the church of St Clement Danes, where Howard was organist. At a different event in February 1774 when Howard certainly did perform (as organist), at a meeting of the Society of Antient Britons, the stewards similarly advertised that the accompanying dinner had been extraordinarily moved for the convenience of attending 'Noblemen and Gentlemen', again to the Crown and Anchor. ${ }^{68}$

Closely connected to the possibility of Howard's directorial role in the services attended by the Westminster Infirmary trustees is the question of whether or not he also acted in this capacity at the Academy during these years. We do know that he was recognized as a conductor: although it now seems likely that it was a different Howard who assisted Boyce at the 1761 coronation at Westminster Abbey, when 'Dr. Boyce and Mr. Howard beat time', ${ }^{69}$ Howard is explicitly named as the conductor at the

${ }^{68}$ London Evening Post, 24-26 February 1774. The Society of Antient Britons was an organization apparently devoted to supporting the children of impoverished Welsh parents, and also involved in the preservation of the 'Antient British language' (i.e. Welsh). It is not inconceivable that the 'anthem' performed on this occasion was 'This is the day' again, though there is no mention either of instrumentalists or a soprano soloist.

69 St James's Chronicle, 19 September 1761. Matthias Range (Music and Ceremonial at British Coronations: From James I to Elizabeth II (Cambridge: Cambridge University Press, 2012), 174-175) 
Anniversary meeting for the Leicester Infirmary at which his orchestral anthem was performed in September 1775 (see Figure 4). The performances at this event were highly praised in the press: 'perhaps the best conducted of any ever exhibited here', as a correspondent in the Morning Post and Daily Advertiser enthused ${ }^{70}$ - though this presumably refers to the 'conduct' of the event as a whole rather than to Howard as director.

\section{[Figure 4 near here, half(?) page-width; caption in separate file]}

The clearest picture of Howard's character as a conductor comes from Laetitia Hawkins, in a passage of her Anecdotes, Biographical Sketches and Memoirs in which she is recalling the acquaintance of her father, Sir John Hawkins, with 'the corps that formed the Crown-and-Anchor concert [i.e. the Academy of Ancient Music] in its primitive simplicity'. ${ }^{71}$ After an extended series of recollections concerning Benjamin Cooke ('librarian and one of the most active of the members', 226), we catch a brief glimpse on page 244 of

\footnotetext{
Dr. Howard, whose powerful arm and paper-truncheon I was so accustomed to see regulating the movements of an orchestra, that I felt jealous for his right, when his office devolved on another - Mr. Aylward the Gresham professor.
}

Hawkins's evocative language paints a vivid picture of the conducting style of Howard, whose authority clearly made quite an impression on her in her adolescence. We also learn that, like Boyce, Philip Hayes and, before them, Maurice Greene - and as had long been practiced on the continent - Howard favoured the technique of beating time with a rolled up piece of paper in his hand. ${ }^{72}$ Most significant for the present purpose, however, is that Hawkins seems to imply that Howard was a regular director of the concerts, to the extent that she viewed Aylward as a usurper. No date is given for this

assumes this to be Samuel Howard, but recent research by Fiona Smith suggests that it was instead a William Howard, then a member of the Chapel Royal (personal communication).

70 Morning Post and Daily Advertiser, 25 September 1775. Such wording is characteristic of critical notices in English newspapers of the period; more would need to be known about the cultural life of this county town before its likely veracity here could be judged.

${ }^{71}$ Laetitia Matilda Hawkins, Anecdotes, Biographical Sketches and Memoirs, vol. 1 (London: Rivington, 1822), 225.

72 See Peter Holman, 'Before the Baton: A Preliminary Report', Early Music 41/1 (2013), 55-63 at 58. 
recollection, but given that Aylward only became Gresham Professor in 1771 it would seem most likely to refer to exactly the period covered by the performances described in Table 1. Although it is possible that Howard had been directing some time before that, it seems unlikely that Laetitia could have been observing the Academy's meetings much before the mid-1770s, given that she was only born in 1759 .

Taken together with the frequency with which the Academy performed his orchestral anthem - including in 1771, after the first time it was presented, the decision to repeat it at the 'Publick night' a few weeks later - Hawkins's account seems to make it clear that Howard was at least one of the regular conductors of the Academy's concerts between 1769 and 1782 . Whether he was the main conductor is another matter; as Eggington observes, despite the founders' intentions that the direction of the concerts should rotate among a group of seven individuals, both Pepusch and, later, in the 1780s, Cooke, seem to have exercised de facto leadership in their own right. ${ }^{73}$ It does at least seem as though there might be more to learn in this respect about the period between Pepusch's death and Cooke's sole assumption of these duties in the 1780s. The two concerts in 1774 and 1777 which featured 'This is the day', some time after the initial flush of performances in the wake of the Cambridge Installation, would also take on new light if we assume Howard to have been behind them: the first featuring a new concert version of Purcell's Dido and Aeneas, a work which Howard is known to have possessed in score ${ }^{74}$ the second arranged on similar lines but replacing Purcell's music with the serenata Solomon by Boyce, for whom Howard served as assistant.

It would be legitimate to ask whether the apparent popularity of 'This is the day' during the 1770s led to it becoming a classic in Howard's own lifetime. Yet as we have seen, the London performances seem to be directly related to Howard's own performing career; indeed, when we examine too the various performances in the provinces it becomes clear that however successful it was, the fortunes of the work were still closely related to Howard's performing activities and professional contacts.

\footnotetext{
${ }^{73}$ Eggington, The Advancement of Music, 50-51.

74 See A. Margaret Laurie, 'Allegory, Sources, and Early Performance History', in Henry Purcell, Dido and Aeneas: An Opera, ed. Curtis Price, Norton Critical Scores (New York: Norton, 1986), 42-59 at 58. The manuscript in question seems unlikely to be British Library, Add. 15979 as Laurie suggests, however, since the previous item is dated after Howard's death. Neither is it identifiable in the sale catalogue of Howard's library (Collection of Old Music), though this does not necessarily mean that it was not included in the sale since several lots seem to be loose descriptions of multiple items.
} 
Returning to the Leicester performance, for example, it should be recalled that Joseph Cradock, patron of the Leicester concerts and author of the Occasional Ode set by Boyce for the occasion, had also been in Cambridge (as we have seen) in the week of Howard's doctoral graduation; together with Howard's close working relationship with Boyce, this connection would have been one of many that might together have led to his engagement for the Leicester concerts. ${ }^{75}$ Similarly, the four performances of the work at Three Choirs meetings between 1771 and 1781 - two of them in Gloucester seem likely to be attributable to the appearance of the Gloucester singers in Cambridge that same weekend, as we saw in Thomas Gray's correspondence. It would be unsurprising, given this precedent, to find that 'This is the day' was also performed in Salisbury, though unlike those for the Three Choirs meetings the contemporary advertisements for the annual Salisbury Festival rarely specify the anthems to be given at the festival Matins. On Friday 26 August 1774, for example, the music consisted of 'the TE DEUM, JUBILATE, and ANTHEMS, with instrumental accompanyments; the whole to conclude with the Coronation Anthem, God Save the King' (the latter almost certainly Handel's 'Zadok the Priest'). ${ }^{76}$

Tellingly, performance of Howard's anthem seems not to have continued after the composer's death. 'This is the day' does not appear at all in the register of performances by the Concerts of Antient Music (RCM MS 1159), which covers the period 1776-1793 - a particularly curious omission given the role of Joah Bates in the genesis of the work. I have also been unable to find any reference to its performance at the Academy of Ancient Music or at any Anniversary meeting or festival performance

75 This concert may also have had significant consequences for Joah Bates, if it was the occasion on which (as widely reported) Howard encountered the 'English musical phenomenon' and 'Lancashire St. Cecilia', Miss Harrop, in Leicester; Howard's enrapture was such that Bates was dispatched from London on behalf of Lord Sandwich's Catch Club to bring her to the capital, and the two were later married (see The Lady's Magazine 12 (1781), 525-526). Standard biographical accounts (NG and $O D N B$ included) garble the story by referring to 'Dr. Howard, of Leicester', perpetuating an error already present in Anon, 'Mr. and Mrs. Joah Bates: A Distinguished Amateur and a Notable Singer', Musical Times 46/1 (1905), 13-20; see, though, Betty Matthews, 'Joah Bates: A Remarkable Amateur', 750.

76 London Evening Post, 2-4 August 1774. Compare, though, the similar description for Friday 19 September 1777, where the canticles and anthems are described as 'accommodated to the muchadmired Church Music of some of the most eminent Italian Composers' (London Chronicle, 19-21 August 1777). 
after its last appearance at the Three Choirs meeting in Gloucester in $1781 .^{77}$ Ironically, by the time Samuel Reynolds Howard made his overt claim for the 'classic' status of the work in print it seems already to have been silent for over a decade.

77 Tantalizingly, a nineteenth-century set of seventeen manuscript parts for the work does exist at the Royal College of Music Library (MS 917). Apparently copied from the exemplar of the 1792 print also at the RCM (D503), once belonging to William Russell (1777-1813), these parts come from the library of the Sacred Harmonic Society, which could certainly have mounted a performance in the 1800s. It is doubtful whether these parts were ever used in a complete performance of the anthem, however, since the alto solo 'Righteousness and equity' was never copied into the 'Alto principle' part (which contains a copy of the transverse flute obbligato part only, pasted in at the point where the solo should be); neither does this movement appear in the main 'Alto' part. 
Figure 1 Samuel Howard, An Anthem for Voices and Instruments (1792): title page (Cambridge University Library, shelf mark MUS.11.8; reproduced by kind permission of the Syndics of Cambridge University Library)

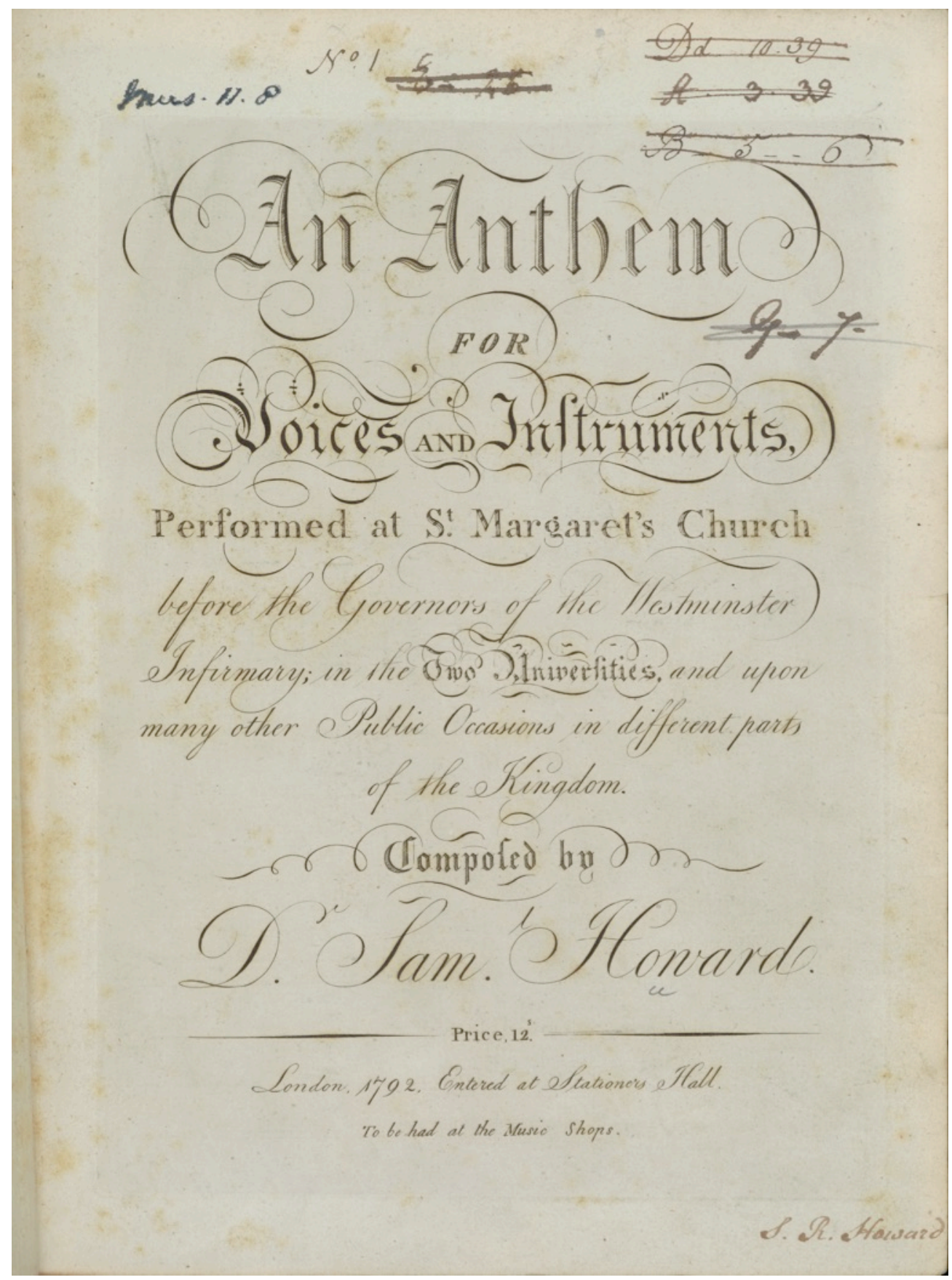


Figure 2 Cambridge University Archives, Supplicats for Degrees, Supplicats 67 (17681769), item 101 (reproduced by kind permission of the Syndics of Cambridge University Library)

$$
\text { Lose Kegal } \mathrm{H}
$$

Supplicat Reverentizs vestris Samul Howard

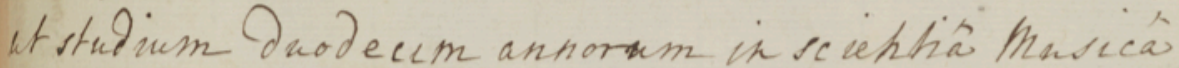
whacum a fidine yiss praxi X sum ma aplonplatione

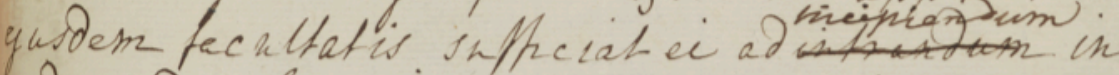
eadem Facaltate itatamen ut Canticum componat coram volis in Eeclesiá Beata Mance solenniter cantandum.

$$
\text { (Solis Pates Polector }
$$

Led. 4 Concefo. $29^{\circ}$ Iunin 1769

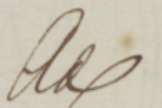


Figure 3 Public Advertiser, 4 July 1769 (C) British Library Board, The Burney

Collection of Seventeenth- and Eighteenth-Century Newspapers; image obtained via the ' $17^{\text {th }}-18^{\text {th }}$ Century Burney Collection Newspapers' database, Gale Digital Collections, by permission of Cengage Learning)

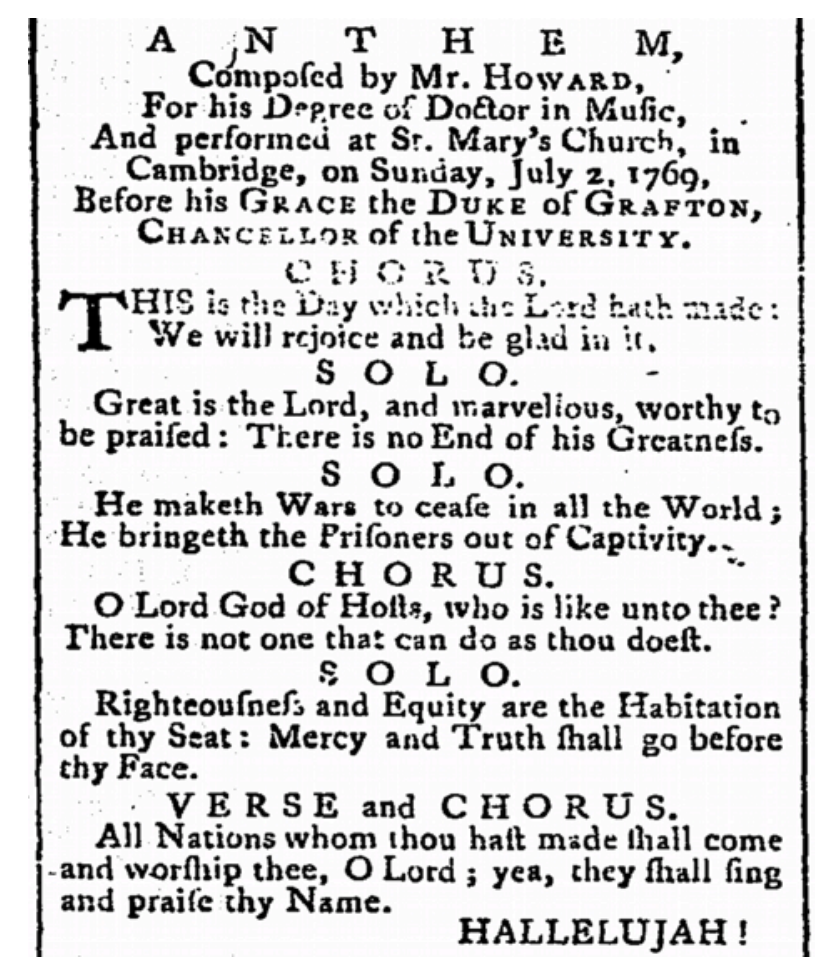


Figure 4 St James's Chronicle, 22-24 August 1775; see also London Evening Post, 2224 August 1775; Derby Mercury, 18 August 1775 (C) British Library Board, The Burney Collection of Seventeenth- and Eighteenth-Century Newspapers; image obtained via the ' $17^{\text {th }}-18^{\text {th }}$ Century Burney Collection Newspapers' database, Gale Digital Collections, by permission of Cengage Learning)

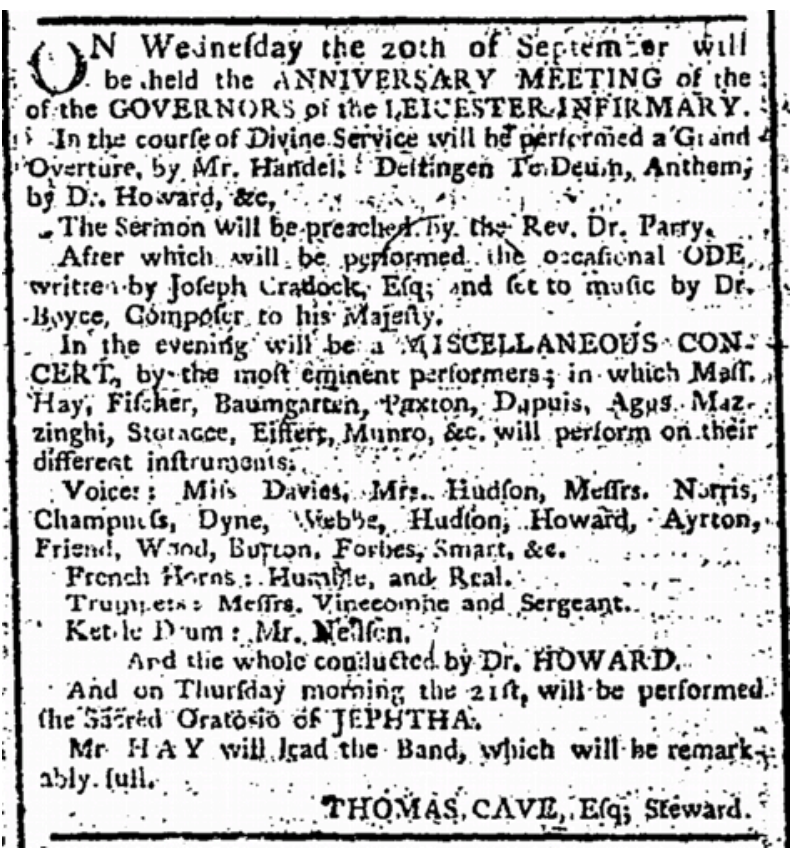

